\title{
Chapter 6 \\ The Use of the UDL Approach as a Factor in the Success of Inclusive Education Despite the Pandemic Period
}

\author{
Jolanta Baran (1), Tamara Cierpialowska (D), and Ewa Dyduch (i)
}

\begin{abstract}
The action research reported in this chapter lasted for one semester. This was a novel time because schools, due to the COVID-19 pandemic, suspended their in-person activities and implemented online learning. This has necessitated the formulation of research purposes and problems appropriate to the dynamically changing educational reality (and beyond). This chapter provides a theoretical background to the risks to education during a pandemic. The assumptions, implementation and results of the research project implemented by the action research method in the selected Polish class are also discussed. The empirical data, mainly qualitative, triangulated by various sources of information, reconciled perspectives that were used to identify specific topics and threads appearing in the gathered inputs, to present it in an orchestrated manner and to interpret it. The analyses carried out lead to the conclusion that the application of the UDL approach promotes the success of inclusive education, despite the difficult experiences of the pandemic period. It has been proven that UDL approach implementation has a positive impact on the course of the teaching-learning process, optimises it to enhance the activity, commitment, self-reliance and responsibility of students and develops their cooperation, which breeds inclusion in education. The extraordinary situation faced by teachers and pupils due to the need to switch to online learning, contrary to temporary concerns, has reinforced the changes brought about by the implementation of the UDL approach in the learning process.
\end{abstract}

Keywords Inclusive education · UDL · COVID-19 · Online education · Teachinglearning process

\footnotetext{
J. Baran $(\varangle) \cdot$ T. Cierpiałowska $\cdot$ E. Dyduch

Pedagogical University of Krakow, Krakow, Poland

e-mail: Jolanta.Baran@up.krakow.pl; tamara.cierpialowska@up.krakow.pl;

ewa.dyduch@up.krakow.pl
} 


\subsection{Introduction: Education in the Pandemic Period-Risks and Opportunities for Changing the Teaching-Learning Process}

The COVID-19 pandemic and the closure of schools have put teachers and pupils (and their parents) in a new, extremely difficult situation. This brought a great challenge to the entire educational environment, which had to adapt rapidly to the new working conditions. As a matter of fact, the pandemic and its limitations are seen in terms of difficult situations (Sliż, 2020) and even shock (Cellary, 2020) in many areas of human activity, and in a particular way, this shock has affected education.

As Jemielniak $(2020,35)$ somewhat humorously notes, the need for a sudden transition from traditional to online learning occurred so violently and shockingly that 'the rapidity of change can be compared to learning to swim by participating in a Titanic disaster'. What happened in spring 2020 in education has been referred to as emergency online learning, that is, 'emergency transfer to cyberspace of forms of education' previously implemented in the traditional way (Kraśniewski, 2020, 40).

Although online education has advanced a lifeline during the pandemic, both scientists and practitioners agree that there are a number of different risks associated with changing education from traditional to online form. Many schools have started to change the form of teaching from at-school education to online education. It should be noted with sadness; however, that in Poland not all students have had the opportunity, especially during the beginning of the pandemic, to take full advantage of online learning, as some of them did not have their own computer equipment or were in need of sharing it with other family members. This situation has carried the risk of digital exclusion (Cellary, 2020) and, in addition, cost to education. In this situation, it is worth looking for innovative solutions and drawing on the experience of those who have been conducting online education for a long time (Tomczyk, 2020).

Among the risks associated with students staying at home and participating in education online, there are a whole series of worrying problems. The first is associated with a negative impact of this situation on the psyche. For every person, especially at a younger age, this new, hitherto unknown situation can result in a threat to mental health and can be accompanied by anxiety and a sense of uncertainty (Poleszak \& Pyżalski, 2020). It is also difficult to control organisational issues. Thus, students who have hitherto been heavily guided and controlled by the teacher in a Polish school have had to take care of self-organisation and self-discipline themselves.

Online education also loosens peer ties and causes social isolation (Pyżalski \& Poleszak, 2020). Limitation of social contact, especially with peers, can have serious consequences for a child's well-being and emotional development, which is why it is so important to support students in maintaining relationships with other children. The child, without participating in real-life social situations, gradually ceases to understand them. As a result, he/she can feel lonely and misunderstood and rebellion and aggression can emerge. That is why it is so important to create 
opportunities for cooperation, for example, by planning online teaching tasks in such a way that they require group work.

The fact that sitting in front of the monitor for hours causes musculoskeletal disorders and causes visual impairments cannot be underestimated. Prolonged sitting and constant homogeneous movements (e.g., typing, using the mouse) strain the muscles in a static way and put pressure on the intervertebral discs.

Therefore, people sitting too long and too often at the computer are more likely to have spinal defects, scoliosis, pain in the neck, shoulder girth, back (especially lumbar region) and hands (especially hands). Intense and prolonged light stimuli coming from the monitor strain the eye, causing redness, burning and tearing of the eyes and blurred vision (Kukułka, 2006; Garwol, 2017). In addition, children who spend hours in front of the computer using the Internet may begin to treat it as an oracle and indiscriminately believe in its content, putting total confidence in its unlimited (in their view) possibilities. Instead of creating themselves and the world around them, they may begin to think and act schematically. Because of the impoverishment of contact with other people and the limitation of their knowledge to the virtual world, their knowledge of the real world may be incomplete. Modern media used in excess have a negative impact not only on physical and mental health, but also on attention, memory, intellectual abilities, creativity and time management (Piecuch, 2016; Furmanek, 2014).

Access to the vastness of information on the Internet, closely linked to online teaching, is, on the one hand, an opportunity for continuity of education. On the other hand, it should not be forgotten that, as Cellary $(2020,22)$ points out, 'the Internet contains everything and denials of everything: what is good and what is bad is beautiful and hideous, ethical and unethical, precious and not, important and invalid'. Jemielniak $(2020,36)$ argues that 'students participating in online education may be tempted to multitasking-seemingly attending online lessons, while also dealing with other activities, e.g. playing a favorite game or even ... nap'.

It is very tiring to participate in online lessons for many hours. The human brain is not adapted to this form of contact with other people. 'Even small distortions of sound or video transmission and the limitation or even inability to observe the mimics or speech of the other person's body require considerable additional perceptual effort' (Jemielniak, 2020, 36; Kaczmarzyk, 2020). It is not insignificant that children-no less than adults-also feel tension and anxiety associated with the threat to their family's health and economic situation, while experiencing helplessness and lack of impact on the situation.

Online learning is associated with risks not only for students, but also for teachers. Of course, like students, and probably even more tired of the situation's social and physical discomfort, they experience anxiety associated with a sense of danger to their lives and loved ones. They are accompanied by a sense of great responsibility, including towards their own students and the parents of the students.

The reports on online teaching in Poland show that 'teachers, especially in the initial period of online learning, experienced understandable discomfort due to a lack of technical competence- - they did not know or did not know enough online learning tools and, of course, in this situation did not have the proficiency in using 
them' (Kraśniewski, 2020, 46). 'Many of the teachers even experienced a very strong fear of new technologies and new media' (Skowron, 2020, 140).

Another problem for teachers is that in the age of online education there has been a complete blurring of the work-home barrier. 'Many teachers worked while having to take care of their own children, organising care for them on their own, cooking lunches and helping them learn and organise leisure time' (Jemielniak, 2020, 35). What is more, it is well known that working almost all day becomes much less effective or even inefficient. 'The challenge for teachers was not only the transmission of knowledge, but also the verification and evaluation of learning outcomes. And this was recognised as an important issue at every level of education, from elementary to university education' (Kraśniewski, 2020, 41). It should have a form of assessment for learning (Sterna, 2020). The situation of teachers is hardly improved by the fact that at the legal and formal level there is a lack of precise regulation of teachers' duties (Koncewicz, 2020).

In the situation of online teaching, based to some extent on self-searching for information and deciding which is valuable and which is not, teachers face a unique task. Although they have lost their dominant position and are no longer the main source of information, knowledge and skills, they must remain, according to Cellary (2020, 22), a 'reference point and ordering factor' and must help students 'focus on learning what is important and forward-looking, rather than wasting time on what is superficial, though attractively given'. Thus, the teaching profession at every level 'is becoming one of the most changing in the near future' (Cellary, 2020, 22). Paradoxically, the difficult reality that teachers, students and parents have had to contend with every day of online teaching/learning may bring a lot of good in the field of education (Walter, 2020). The pandemic is not only a litmus test of the digital competences of teachers, pupils and the degree of preparation of schools for crisis situations, but also a test of empathy, humanity and ordinary human kindness, and makes them aware of the importance of these values.

The situation of school closures will certainly change the approach of many principals and teachers to the digital school. It will mobilise to retrofit institutions with the right equipment and start a period of real development of the competences for the future in our schools. The experience of online learning can also contribute to moving away from traditional teaching, from lectures serving students with readymade content in favour of more independent learning, seeking information, selecting it and thinking critically.

Physical isolation from peers could also make us realise how important another person is and how relationships with others are needed and teach us how to take care of those relationships. Perhaps the transition to online education will also lead to a paradigm shift in education and an understanding that education is not the most important core curriculum, assessment or factography, but self-planning and organisation of learning, which can be beneficial for the whole of a human life. 


\subsection{Research on the Experiencing of UDL Approach Implementation in Online Education During the Pandemic}

The subject of the research presented here was one VI-grade class at a public elementary school. The research was conducted during the spring semester of the school year 2019/2020. There were 17 students and a team of four teachers in this class of integrated form, which means that there were some students with SEN included in this group of students. The aim was to simultaneously capture the process of teaching-learning taking place in the examined community, as school education is understood as an interactive relationship between two simultaneous subprocesses: teaching (teacher activity and reflectiveness) and learning (student activity and reflectiveness). Thus, the main focus of the researchers was the course of change that took place in the teaching process - the learning among students and teachers influenced by UDL approach implementation in this classroom (Creswell, 2013; Rose et al., 2005).

According to the assumptions, the research was carried out using the action research method (Szymańska et al., 2018; Szymańska, 2018; Czerepaniak-Walczak, 2014; Pilch \& Bauman, 2010; Sagor, 2008). The action research project reported here was launched at the end of February 2020, at the time of the outbreak of the COVID-19 pandemic in Europe, including Poland. The lockdown situation was so surprising that the researchers initially feared that the research project would have to be suspended. While the Polish schools implemented quite quickly various forms of online teaching, it was an extremely difficult situation for all those involved in the education process, from the educational authorities, through teachers, parents and, above all, students, who were necessarily expected in the new situation to be much more involved than ever before in the process of knowledge and skills acquisition.

Our previous experience of conducting a research project on attempts to implement UDL to work in a diverse group of students has identified barriers and positive innovation outcomes to the teaching and learning process (see the previous two chapters). Therefore, it was decided to conduct further studies to identify the conditions supporting the change and its active mechanisms. It was decided that supporting and consulting teachers on strategies to work with students would be based on the implementation of the UDL approach. Research assumptions therefore included the following objectives and problems:

- How do teachers and students show their willingness to change the teaching/ learning process and to follow-up changes initiated by the previous experience with a further project and research?

- To what extent do teachers give students choice (purpose, forms of work, ways of knowledge and skills acquisition, including teaching resources and methods, ways of assessing knowledge and skills)? 
- How does the relationship between teachers and students and between students and each other change during the course of action (and how does cooperation develop)?

Because of the COVID-19 pandemic and the transition of Polish schools to online learning from the beginning of March to the end of the school year, an additional research problem was formulated regarding the impact of the situation and the forced change in the form of teaching-learning while implementing the UDL approach as well as its effects, that is: In what way and to what extent have teachers and students used their experience and continued to apply the UDL approach to the teaching/learning process during online teaching?

- Did the experience with the application of the UDL strategy have a positive impact on the teaching/learning process in the online teaching period and in what way?

- Were there any difficulties, and if so, what were they with the UDL approach implementation in the online teaching process?

Researchers have only assumed that they will remind teachers about the UDL strategies and encourage them to try to implement these strategies also through online forms of educational efforts.

The content of data collected was analysed due to the constant comparative method (Creswell, 2013). It is applied to identify topics and their specific threads in the data obtained through the research process, which were previously transcribed and encoded.

In order to ensure the accuracy and reliability of the analyses presented below, a communicative validation procedure was applied (Szmidt \& ModrzejewskaŚwigulska, 2015). It consists of presenting the subjects and threads selected in the analysis process and reconciliation of the interpretations made with them.

It should be noted that the lockdown of Polish schools in the first days of March 2020, in relation to the nationwide lockdown, has never been seen before and proved to be extremely difficult for all entities involved in the education process. One of the teachers described the situation in which the students and teachers, but also the educational authorities, headmasters and the students' parents, were referred to in a direct manner:

Teacher Cecil: None of us was prepared for this. (Reflection with researcher, 48)

Nevertheless, the teachers quickly implemented distance education.

Teacher Agnes: I started to teach through the Zoom platform already one week after school lockdown. (Reflection with researcher, 46)

Other teachers also used this platform for online teaching purposes. For us, researchers, it was important that online teaching should take into account the assumptions of the UDL approach, although we decided that, in these difficult times, we would not interfere too much with the course of the teaching/learning process, but would limit ourselves to encouraging teachers to continue the UDL 
approach implementation in this unusual, online form of work and, as far as possible, we would support them in this respect.

The empirical data, which represent the basis for these analyses, were obtained using the following techniques:

- The survey form - the teachers of Polish language, mathematics and history completed the form that concerned their reflections on the application of the UDL principles in their online classes.

- If the female teachers indicated such a need, they were given individual methodological support on the phone and current problems that emerged in the course of distance learning classes were discussed; such telephone consultations took place at least once a month.

- At the end of the semester, students expressing their willingness were interviewed individually through the Zoom platform to discuss their learning experiences as enriched by the UDL strategies during their distance education.

- Summary focus group interview with the teachers via the Zoom platform was carried out.

The analysis of the data collected in this manner brought the following findings, which, following the footsteps of Cycle Two of action research, were arranged in two phases.

\section{Application of UDL Methods in Distance Education}

Teachers, despite the difficulties they experienced in switching to distance education operations, unknown to them so far, continued to try, although - as they themselves admitted not as intensively as before - to carry out the teaching/learning process following the UDL principles.

As part of their efforts, it was important to seek to propose objectives that are understandable to students, and to emphasise their usefulness. Teachers made it easy for students to present the goal(s) of their lessons so that they could consciously participate in the teaching/learning process.

Teacher Bella: I explained to them exactly what they would learn and why. They liked the objective. (Reflection with researcher, 47)

Further, from the students' perspective it is clear that the way of making them aware of the class objectives was clear and transparent. Students' utterances can serve as confirmation:

Nina: The teachers at the beginning of the classes said what we would be doing, what we were going to learn. (Reflection with researcher, 41)Kamil: Teachers said what we would learn and how. (Reflection with researcher, 43) 
The analysis of teachers' and students' statements leads to the conclusion that in the online teaching environment it was also possible to implement one of the major UDL principles, that is, to present the theory in practice.

Teachers use different forms of action and expression to encourage greater student activity. Thanks to the application of the UDL approach principles, teachers, in order to enrich distance teaching, have sought to offer their students various forms of activity and expression. They have tried to give students, at least in selected lessons, the widest possible choice of ways of achieving the goal or forms of work. One of the female students reports the essence of distance education according to the UDL in the following manner:

Mira: There were some projects, for example, at maths classes. There were three options to choose from, that is, tasks, for example, crossword puzzle, word puzzle or rebuses. (Reflection with researcher, 36)

As an example of educational classes conducted in accordance with the UDL rules, the Polish language teacher mentions a lesson about a Polish author of fantasy literature, Stanisław Lem, and its objective was to make a contribution to the development of the Polish language:

Teacher Agnes: To activate your creativity. The topic was 'We are creative in the world of Stanislaw Lem'. I gave them five choices. They were incredibly happy because they could get connected outside the class and work together. And certainly it was not compulsory. They could prepare, they didn't have to, although I encouraged, they could work in groups and they could work individually. ... Most of them worked in groups. (Reflection with researcher, 46)

Another class enriched with the UDL approach also seems to be very interesting, this time history class, which is described by the teacher of this subject as follows:

Teacher Cecil: They had a choice of three types of Assignment 1. The first assignment was for those who like to count, a bit of maths and a bit of history, the second assignment was for those who like to draw. The students were required to create a historical glossary with the terms we used and to illustrate them. The third assignment involved development of a biographical dictionary. You had to search for some titbits or sentences about selected characters. (Reflection with researcher, 48)

Thirdly, in accordance with UDL principles, teachers promoted cooperation as a form of supporting commitment. It turned out to be very important to respect another UDL principle, namely to promote cooperation, perceived as such a form of in-class work. Distance, also, most effectively supports students' commitment.

Mira: You could do something on your own or to team up with someone. I chose a group, because then you can help one another and learn the most, and it is more fun. (Reflection with researcher, 36)

The students worked together mainly via the Zoom platform. One student reported in detail on the form of collaboration related to distance teaching enriched with the UDL approach: 'We held the meetings via Zoom platform. We set the time of meetings and I, for example, would send a link'. To the researcher's question: 'How big were groups that you formed?' the female student explained: 
6 The Use of the UDL Approach as a Factor in the Success of Inclusive Education...

Mira: Any size that we wanted. Usually four persons. We work together a lot. (Reflection with researcher, 36)

Joint work via a distance teaching system based on the UDL principles was an opportunity to learn compromises. The following statement can be used as an example here:

Kamil: We decided together how we would do it. We would come to a consensus how to do it. Then we voted. (Reflection with researcher, 43)

Having no option for direct contact made the students aware of the value of community, which is documented in their reflections as follows:

Mira: Actually, we've become more fond of each other; everyone wants to know what's going on now. (Reflection with researcher, 36)

Meetings via instant messaging were not only related to learning itself, but also satisfied the need for social contact between the surveyed teenagers.

To the researcher's questions: 'Do you miss one another?' the students answers were positive. The following statement of a female student can be used as an example here:

Mira: Yes, very much! And from time to time we arrange to meet via Zoom platform.

Frequently. (Reflection with researcher, 36)

The teachers of the surveyed class took care to maintain the feeling that students belonged to one community. An interesting idea that the students liked very much was a class during which they browsed through the photos taken during school trips.

Teacher Cecil: It followed 'let's experience that once again' principle. (Reflection with researcher, 48)

During online teaching, not only was cooperation between students very important, but also cooperation between teachers and students, which, in the case of the class under examination, as the analysis of the material obtained during the research shows, went far beyond the formal framework. Students could get in touch with the teacher whenever they needed his/her assistance.

Kamil: There was an option to hold one-to-one meeting with the teacher, if his or her assistance was needed. (Reflection with researcher, 43)

Teacher Bella: I would also get connected with kids in the evenings. (Reflection with researcher, 47)

The students' needs for cooperation and contact with others varied from one case to another. In any case, the teachers approached the students on an individual basis, accommodating those who had the need for more intensive contact.

Teacher Bella: $N$. wrote, rang me and she really needed that kind of attention and contact. Well, I worked a lot with her, we solved problems together, we also talked on the phone. (Reflection with researcher, 47)

Positive experiences related to tutoring (teachers' and peers') meant that, despite initial concerns about the value of distance education, it was possible to achieve its 
objectives, and with regard to some students, the distance teaching performance turned out to be unexpectedly good. Teachers had a very positive opinion of distance work in the surveyed class, as evidenced by the following quotations:

Teacher Bella: Class VI passed the exam very well, because I can compare it with another form of course. I'm impressed with our children attending Class VI. ... In-class work was fun. Children worked, volunteered to answer questions. They always switched on their Web cameras. ... I'm impressed with our children attending Class VI. (Reflection with researcher, 47)

Probably among the reasons for this is the fact that students were able to learn 'on their own terms' to a much greater extent than before, which goes hand in hand with the philosophy of the UDL.

Lena: There was more time for tasks. It was more comfortable because it was at home. No need to get up so early. More time for writing. (Reflection with researcher, 37)

Teachers also maintained very good contact with the parents of students at all times, realising how difficult the situation of parents has become in relation to the transfer of students' education venue.

Teacher Cecil: I was up to date with them (parents), actually 'on the phone', because these calls appeared quite often. ... We were on the phone all the time, whatever happened, these parents practically called me at least two to three times or even more during this period; they called and talked to me. (Reflection with researcher, 48)

Thus, online education during a pandemic would not have a chance of success if it had not been for the close cooperation between teachers, students and parents, and primarily among students. The experience of cooperation makes students aware of its value, which is a kind of capital, which hopefully will be taken advantage of in the future. A positive assessment related to the experience of cooperation in a group caused students to declare that after resuming their education at school they would try to cooperate with each other as much as possible.

Lena: More workgroup. (Reflection with researcher, 37)

Kamil: I want to work in a group, because it is easier. (Reflection with researcher, 43)

When participating in online education, teachers and students necessarily used modern teaching aids in their work, which is consistent with UDL principles. Interestingly enough a kind of paradox emerged during interviews, both with students and with teachers. Students became bored with free access to modern technologies after some time and then started to reach for books in the traditional (hard copy) format, which, according to researchers, is a positive phenomenon, and although it seems that it is not entirely in line with the UDL principles, it can be described as 'everything old is new again'.

Teacher Cecil: You had to look for it in the textbook, you had to look through it, because some people, I suppose, often don't look through it (they didn't look through it before), and here ... you had to work with the textbook in this manner clearly. I think it's good, because sometimes I feel like we hand them everything on a plate. ... I remember my education in such a manner that it was me who was looking for myself and it was me who was flicking 
through the textbook. So I think it's good, and it's worth continuing sometime. (Reflection with researcher, 48)

Thus, the online work forced students to search for information on their own in a conventional, but valuable source: a school textbook.

\section{Positive Impact of Previous Experience with the UDL Approach on Online Education}

In the online teaching period, previous experience of teachers and students related to the UDL approach implementation in the teaching/learning process had a positive impact on the educational, but also social aspects of the functioning of teachers and students.

The analyses carried out make it possible to conclude the maintaining of a high level of motivation and commitment to continuing a fully-fledged learning process-learning in the times of online teaching. The researchers' tracking of the reports (Pyżalski, 2020) evaluating online teaching in Polish schools makes it possible to conclude that the teachers participating in the project belong to the group of those who made great efforts to continue teaching and fully implement the curriculum despite the schools lockdown. This certainly involved a great deal of work, but as the teachers themselves stressed, their sixth-grade students demanded activity and tasks consistent with the UDL approach.

Teacher Dalia: At our school, all classes were organised and all the extra and compensatory hours, and all those divided into groups. Actually, they had plenty of it. They were willing to participate in it. (Reflection with researcher, 49)

Teachers also have a very positive view of the students' commitment at the surveyed class, as the students participated systematically and actively in the in-class activities.

Teacher Cecil: Generally speaking, the online classes were characterised by a very good attendance rate. With one exception, the remaining children, I am talking about the whole class, participated in these classes very systematically ... An advantage for us was that these kids showed via web camera and were visible in a window, because we have a comparison with other forms, so it's much easier and more enjoyable to work when I see a kid. Then, for example, at a secondary comprehensive school, where we don't see anyone and talk to the screen and the response is so weak. Meanwhile here we had dialogue, the exchange of opinions, and it was easy to work because these children were visible. (Reflection with researcher, 48)

One of the teachers directly defined the students' willingness to learn by saying:

Teacher Bella: They all brought themselves to learn so hard. (Reflection with researcher, 47)

The students' involvement, their mobilisation and willingness to learn online were certainly linked to the commitment of the teachers, who swiftly implemented the online classes and held them in a very reliable manner. 
Teacher Bella: And they had so many online classes that sometimes I already counted: 'oh, they already have five, so I can't report the sixth one (to the headmaster)'. Because the headmaster said that five online classes was maximum and one should not exceed this daily threshold. In our case we went in the opposite direction. We had so many distance education, that we had to watch not to have too many of them. ${ }^{1}$ Yeah, I think we were all trying very hard at this point. (Reflection with researcher, 47)

In their utterances, the teachers also compared the Class VI covered by the project with other forms and emphasised that the students in Class VI showed aboveaverage performance and worked with high commitment.

Previous experience in enriching the UDL in the learning process has resulted in an increase in the development of students' skills involving planning, organisation and managing their own learning process. The lockdown created an opportunity for students to become more independent, including making decisions on their own. Especially in the initial period, it was not easy, but with time it turned out that the students were doing well. Despite the initial hardships, students became more and more independent.

Teacher Bella: Initially there was also a problem with connections. Mom (of H student), before they came to the conclusion that $H$ should also work independently. Later H learned beautifully how to work independently, really. But at first he was scared, and his mom was scared. His mom worked, he was alone. Yeah, the organisation was tough at first, but then it all came out beautifully. After some time H sent everything beautifully on his own, I was impressed.... I asked the other children each time at the beginning whether Mom helped to send (online tasks), whether Dad helped to send or whether they sent on their own. Later on they boasted themselves that they could do a lot of things on their own. (Reflection with researcher, 47)

Teacher Dalia: Online teaching taught them to work so independently. (Reflection with researcher, 49)

In turn, a female student reports on the development of her independence through the online learning process in the following manner:

Nina: Now I had to be more independent, to take decision about timing and what to do (the researcher's question: 'And what happened? Did you succeed?'). Yes, I did. (Reflection with researcher, 41)

This observation is shared by teachers, who note that for many students, even those with greater difficulties in their daily lives, distance education is conducive to plan their learning and organise their education.

Teacher Cecil: Some children have learned to organise their time and to plan. Our parents told us that even children with medical certificates, here is the example of a student with Asperger's syndrome. At the beginning it was just one big mess, no organisation at all, he got lost, he didn't know how to attack this problem and only when he grew to the new

\footnotetext{
${ }^{1}$ The school ran lessons in various forms, and distance learning classes (online webinars) were only a part of them. The decision on the form of classes was made by the teachers. Students attending Class VI had their classes delivered mainly in this way. The school management warned the teachers not to expose the students to 'digital overload'.
} 
environment, he opened some kind of notebook on his PC. (Then) he would send the assignments back on time, he would connect regularly. (Reflection with researcher, 48)

Teacher Bella: There were students who started to work much nicer under the online teaching system than at school. There were people like that and I was so surprised ... they said that they were more motivated by online learning ... there were people who really developed wings. (Reflection with researcher, 47)

Teacher Bella: At the end of the day, she did that systematically ... There were people who were helped so much by this, they mobilised themselves to work and also believed they could do it. (Reflection with researcher, 47)

Some teachers associated the observed change directly with the reduction of their dominance in the teacher-student relationship, because in online teaching additionally enriched with UDL principles, the teacher's role becomes less dominant. One of the teachers put it bluntly:

Teacher Agnes: Well, I was kind of a mentor. (Reflection with researcher, 46)

The students accept an increase of their roles in the teaching/learning process:

Lena: Teachers told us what problems we had to solve and we had to organise it ourselves. (Reflection with researcher, 37)

It seems that, thanks to previous experience with the UDL approach, there has also been a noticeable change in the development of independence, responsibility, creativity and problem-solving skills of students. Evidence of the responsible involvement of students in the teaching/learning process occurred through support for other colleagues, or even a teacher, when help was needed to deal with IT tools at a distance.

Teacher Agnes: The class behaved very nice, they helped me very loyally, because they know that I am an IT loser. And L would simply say: 'Madam, you click here, you click there'. I did it and it always worked. (Reflection with researcher, 46)

One of the teachers revealed the mechanism of awakening students' responsibility and moving from external to internal motivation:

Teacher Bella: Those who didn't want to connect, didn't want to solve problems, we didn't punish (with bad grades). I even rebelled at the beginning when the headmaster said 'don't give any Fs'. Well then ... let it be their business, we ask them, we admonish them and so on and so forth, but (the point is) that they should feel responsible, they should see the difference now. It's harder now and it's on their shoulders now. (Reflection with researcher, 47)

Importantly, the level of their self-awareness and self-esteem is also growing, which was confirmed by the following statement made by a female student, who was previously known as a girl having problems with ADHD, finding it difficult to concentrate on other people's statements and demonstrating low activity during classes.

Lena: It's for sure that I'm more thorough now, because I'm giving up the problem now and (here the question confirms) I have such a feeling that this is my responsibility. (Reflection with researcher, 37) 
As a result of the UDL approach implementation, students' creativity also increased under the online teaching system. This is testified to by the following statement:

Lena: We shared tasks. At maths classes you could do a mathematical crossword puzzle, or there was a rebus or some kind of riddle. It's faster, there are different ideas. Everyone submits their idea and then we proceed to vote. (Reflection with researcher, 37)

\section{Reasons for the Limited UDL Approach Implementation Under the Online Teaching System}

Although teachers clearly perceived the benefits of using their previous experience of UDL approach implementation in the teaching/learning process during the difficult times of online teaching, which has a positive impact on the learning community, they acknowledged that they did not apply the UDL approach as often as it was intended during the past semester.

Among the reasons for the limited implementation of the EDL strategy in online teaching, the teachers pointed out, among other things, were the technical issues that had to be addressed when switching to online teaching. The situation was particularly difficult at the beginning when teachers and students had to master online tools, but in hindsight, the self-esteem of teachers and students was clearly positive in this respect.

Teacher Bella: None of us was prepared for this. So I think we mastered these technologies quite quickly and, well, it wasn't easy for everyone. For us, too, it was stressful before we got to it. (Reflection with researcher, 47)

It is important to realise that in the process of distance education, objective technical obstacles, such as lost connections due to Internet congestion, appeared more often at first and then fortunately less frequently. In every house, children learned and their parents worked online, so at the same time, the Internet was used intensively by many people. It was an important obstacle to education in general, and in the teaching/learning environment reinforced with UDL strategies, that is, more diverse in nature, it could be a very important obstacle.

Nina: Unfortunately, during classes frequently Internet lags occurred (in the sense that students were disconnected from the Internet). (Reflection with researcher, 41)

Still another problem, also related to technical problems arising in the situation of non-direct contact, is the difficulty of discussion, which is inextricably linked to the UDL approach.

Teacher Bella: If the group was preparing a task, everyone wanted to speak simultaneously. It was four or three people... And suddenly at the place of one of them, for example, a mixer or a vacuum cleaner is on, or there is a renovation activity behind the wall ... It was difficult to report in groups what they had worked on out there. (Reflection with researcher, 47) 
The difficulty that the students noticed was also the lack of direct contact with the teacher, who could not—as was the case in traditional education — provide an immediate response to the difficulties or at least dispel doubts experienced by the students.

Nina: Previously, we had more exclusive contact. We had more chances to ask the teacher for help, for example, to verify some assignment, to give directions somehow, and with this on-line teaching, it was hard to respond immediately in this manner. It was easier at school. (Reflection with researcher, 41)

This is confirmed by the words of teachers who, in an online communication environment, were deprived of the typical tools of keeping disciplined students who were not focused on the course of the lesson.

Teacher Cecil: I felt that I had less power over them ... Reduced capabilities. (Reflection with researcher, 48)

The lack of direct contact meant that the teacher had a limited repertoire of strategies for disciplining students, though not only was he himself not helpless, but he also experienced support from other students.

Teacher Bella: Sometimes we applied mute someone in the class, but this is a great tool, really. (Reflection with researcher, 47 )

In the absence of physical, direct contact with students it is difficult to control housekeeping arrangements. One of the teachers even calls it organisational chaos.

Teacher Cecil: They liked to talk (a lot) during these classes (UDL enriched), it was getting chaotic, after all at such class at school it is easier to master situation. (Reflection with researcher, 48)

In the statements of individual students, there is another reason for difficulties in the distance education system, including working according to the UDL principles. Some students during the early days of the distance education era played their favourite games on smartphones or distracted others by drawing some humorous remarks or drawings on the desktop (blackboard) provided by the teacher.

Kamil: We were disturbed by the classmates playing games during classes. (Reflection with researcher, 43)

Interestingly enough, the sense of responsibility for the group encourages students to discipline one another.

Teacher Agnes: When someone made doodlings on the board, although I learned later where to block it, still they yelled (at one another). (Reflection with researcher, 46)

The analyses also revealed objective difficulties caused by the pandemic situation. Both students and teachers also pointed out that some forms of work, and those in which the UDL principles are 'natural', became completely unavailable:

Nina: Most of all, we miss school trips, performances. (Reflection with researcher, 41)

The teachers agreed with the students. An example is a statement made by one of them: 
Teacher Bella: If there was a school, we would go to the cinema, we would make outings here and there, under current circumstances it was impossible. They had classes day by day. (Reflection with researcher, 47)

This is what, according to the teachers surveyed, made the students-especially at the school year end-less eager to work creatively.

Teacher Bella: They were already tired ... they had enough of everything, they had no power for some interesting ideas, they were simply exhausted. (Reflection with researcher, 47)

Among the reasons for holding classes, in a more directive way, without respecting the UDL principles, where the teacher takes a dominant role and imposes on students the work type, methodology and form, the teachers continued to point out a need to implement fully and completely the overloaded core curriculum.

Teacher Agnes: I had to rush with the core curriculum. (Reflection with researcher, 46)

Teacher Agnes: I had a few more ideas, but due to time constraints, I didn't implement all of them. ... I am lagging behind with curriculum execution. ... The curriculum is extensive and I wanted to execute the most by the end of the year... And I look at it this way: I still have so much to do, and the end of the year is round the corner... I had a few more ideas, but due to time constraints, I didn't implement all of them. (Reflection with researcher, 46)

Thus, the teachers, despite numerous interviews with researchers on this topic, continue to harbour the belief that holding classes in accordance with the UDL principles would not allow them to execute fully the entire curriculum, which they consider to be a prerequisite for reliability and effectiveness of their work. The operational model developed over the years and imposed by the educational authorities makes them unable to accept the idea that giving more freedom to students to choose the content, method and form of work can be much better for students and can have a positive impact on the actual level of their knowledge, skills and social competences rather than execution of the entire curriculum, of which there is often little left in students' memory.

\subsection{Discussion and Conclusions: New Experiences in the Teaching-Learning Process Under Implementation of UDL Approach in Online Education as Steps Towards Inclusive Education}

Summarising the analyses concerning the results of action research presented in this chapter, several conclusions can be drawn.

First of all, in the difficult period of the pandemic, teachers and students used the previous experience they gained in implementation of the UDL strategy in the teaching and learning process. Although, as they themselves noted, they did not do it as often as they did in the conventional form of school teaching. Nevertheless, the teachers made every effort to set goals in a way that was as comprehensible as possible for the students and so that the students could see their usefulness and an 
option of using the acquired knowledge and skills in their own lives in the present and in the future. Although the lack of direct contact made this task difficult, the teachers strived at translating the theory into practice and the students at using the knowledge and skills acquired during the lesson in their own practical activities.

Moreover, the teachers tried to give the students the opportunity to choose various forms of action and expression. As the teachers admitted themselves, this did not happen in every lesson. This fact proves that the UDL approach implementation is an ongoing and incomplete process that, in order to develop, requires constant, although less and less intensive, methodological support. An important factor stimulating this process is that teachers themselves see that giving their students an opportunity to select different forms of action and expression clearly breeds higher activity and involvement from students. Students appreciated this very much and willingly used the choice offered to them.

A key aspect, and at the same time the primary value of the teaching/learning process that is inextricably connected with the UDL approach, turned out to be cooperation, especially in the time of distance learning. This took place in various dimensions. Thus, it was a cooperation of students with one another, cooperation of students with teachers, as well as cooperation of teachers with parents. The analyses carried out allow us to conclude that this cooperation took different forms, depending on the needs of students, teachers and parents. Students willingly formed a cooperative community not only during the lessons but also after school.

Teachers promoted this collaboration as a form of supporting student engagement. The above-average openness of teachers to contacts with students should be appreciated. Almost any time outside classes students had the opportunity for group or individual contact with the teacher. Good contact between teachers and parents was also crucial, as the latter experienced various difficulties in moving a student's education setting and meeting barriers in his/her social and peer interactions. Thus, the close and constant cooperation of students, teachers and parents, one of the key principles of the UDL approach (Meyer et al., 2014; Rose et al., 2014), proved to be a key success factor of the distance learning process.

Secondly, the analyses show that the previous experience of teachers and students in the implementation of the UDL approach in the teaching/learning process has had a positive impact on the quality of distance teaching and learning. The UDL approach kept teachers' and students' motivation at a high level to continue the teaching/learning process online. Taking into consideration the results of the reports on the overall education in the initial period of the pandemic with the associated lockdown, it should be noted that primarily, the teachers surveyed, but also their students, made every possible effort to ensure that the teaching/learning process did not lose its value.

The analysis of the narrative material collected in the course of the research enabled us to conclude that the situation in which the examined class and its teachers functioned not only did not cause any limitations, but on the contrary, it also partly contributed to the development of students' skills in planning, (co-)organising and managing their own learning process. 
Handing over a higher degree of initiative to the students, partly due to the conscious decision of the teachers who had been guided earlier by the UDL approach, and partly forced by the lack of direct contact between teachers and students, turned out to be a factor that fostered the development of the independence, responsibility, creativity and problem-solving skills of students.

All this was done in an atmosphere of teachers' high responsibility for teaching, but also students' responsibility for their own and their group's learning outcomes. Particularly interesting and worth emphasising is the development of mutual support (peer tutoring) among students.

While identifying and appreciating the positive transformations in the teaching and learning process that took place, it should be noted that the material collected during the research also includes a topic concerning the reasons for the limited implementation of the UDL approach in distance education. This limitation was mainly related to the dimension of offering students an opportunity to choose various forms of action and expression in every class. Among the causes of these difficulties, the teachers pointed out first of all the technical problems experienced, especially in the initial period of shift from conventional to distance education.

These resulted from inconsistent quality of the Internet connection, which was associated with its overload or with the fact that teachers and students had just begun to use various new distance learning tools. For instance, it became difficult to hold an in-class debate because holding it via a video connection is not as smooth and natural as during direct contact between teachers and students in the classroom. The lack of direct 'live' contact also hampered quick responses to the dynamically evolving needs of students during classes.

Teachers also pointed out that in the situation of distance education they felt deprived of the typical tools used to discipline students, who during classes, for instance, did not focus enough on the content discussed. It should be noted that under such circumstances, the teachers could count on other students who disciplined one another upon their own initiative. The teachers' and students' statements also document objective difficulties in the implementation of the teaching/learning process related to the duration of the pandemic. It is therefore not possible, for example, to organise trips or outings to cultural institutions or other places, while outdoor learning is perfectly compatible with the UDL approach (Meyer et al., 2014).

A cause for some concern is that some of the difficulties have persisted almost from the beginning of the action research project in the selected class. Difficulties remaining include, primarily, teachers' fear of not being able to teach $100 \%$ of their curriculum on time. Teachers still show a belief, even though it is much weaker than in the previous research (see Chap. 5), that UDL approach-based teaching is more time-consuming and therefore will not allow them to teach fully the entire curriculum, whereas they are convinced that this is a prerequisite for their work reliability. Gradually, however, it can be observed, especially among younger teachers, that their mindsets begin to change and they understand that education is not about teaching the entire material, but about educating the students to develop those features which, in a dynamically evolving world, will enable them to pursue their 
lifelong choices, acquisition and updating of knowledge, responsibility and independence and the ability to cooperate with others.

It is worth noting that the process of change that has been shown is also subject to a variety of situational factors. In the case of this project, the COVID-19 pandemic turned out to be such a factor, which radically influenced the shape of education in general. The change taking place in this extremely different reality was threatened, but paradoxically, the difficult situation has had a positive impact to some extent on changing the teaching/learning process in the surveyed class. As the teachers and students emphasised, this happened exactly because the changes had been initiated and implemented earlier.

The situation in which education has been found itself during the pandemic has posed a number of challenges for teachers, pupils and parents. As Lubacz notes $(2020,5)$, 'teachers and learners have mastered the technical side of teleinformatic tools relatively quickly', but this is not the only problem of online learning. Particular attention should be paid to the quality of teaching relationships with learners and between learners.

One of the most effective strategies for developing and improving the individual and social competences of each student, and in particular those with special educational needs, is group work (cooperative learning, collaborative learning). The essence of group work is:

- Partnership-coordination of entities.

- Interdependence-all members of the group strive to achieve the group goal and help each other to achieve the individual goals.

- Individual responsibility - each member of the group is responsible for their own learning, which in turn helps to achieve the group goal.

- Cooperation - students discuss and solve problems and cooperate with each other.

- Pro-social attitude and humanism - helping, support, solidarity, altruism.

- Evaluation - the members of the group check the results of their work, evaluate them and make the necessary changes. Education in cooperation has clear proinclusion qualities (Bąbka \& Korzeniowska, 2020).

The basis of group work is joint work on the task, connected by a network of communication relations between the members of the group. Communicating with each other not only allows exchanging thoughts, ideas and solving tasks/problems, but also allows:

- Creating active knowledge, for example, that which creates the student's cognitive patterns. It is in the process of work that the student tries to say/name what he/she saw, or did, or what he wants to do or wants others to do.

- Creation of operational knowledge-which is used practically in different life situations.

- Developing organisational skills—initiating activities, stimulating activity, planning and coordination of actions.

It is worth noting that in the process of group work, students support themselves in learning from each other. The motivating of students for cooperation and the 
arrangement of their work in diverse teams is in line with the key principles of improving the quality of education (EADSNE, 2011).

A teacher working in an inclusive classroom must not only work with students, but also with their parents in order to fully carry out their tasks. Until the pandemic, parents had never been expected to 'enter the role of educators of their children' (Amilkiewicz-Marek, 2020, 129) on such a large scale. This matters to every student, but it is especially important for students with special educational needs. This cooperation must not be ad hoc and must not be limited to "mutual information about the child, his behavior and learning progress, but should cover at full scope all the child's needs' (Plichta, 2020, 71).

The well-run cooperation of the family with the school is one of the basic tasks to be fulfilled by the modern school. Working with parents is a kind of support for them, which can take various forms including: class fanpage, electronic journal, SMS, phone calls or emails. Thanks to this, parents participate directly in the teaching process. The interaction of these two environments guarantees the proper relations between the teacher, parents and the student, which are necessary in the child's learning process and, above all, necessary for their proper development. It is therefore desirable and appropriate for parents to actively participate in the education of their children, to co-decide on the course of their children's teaching and learning process (Pawlak, 2003).

Relationships between teachers can take on different dimensions, but in integrated education and inclusive education it is necessary to open teachers to constructive cooperation with different people. Thus, the professionalism of teachers and the duty to provide the highest quality of education for all students requires that they have strong affiliation tendencies and that their relationships in the context of interpersonal communication concern both dominating behaviour (such as initiation, coping, conduct, coordination) and dependency (approval, support/help, cooperation, commitment).

It is to be hoped that — as Poleszak and Pyżalski point out (2020)—-the situation of the pandemic will become an opportunity to build better relations between teachers and parents. The experience of the pandemic has clearly made this clear, but we often forget how important teachers are to the quality of education. In Polish schools, there was a huge variation in the way online classes were organised and conducted. This differentiation was linked to a number of different factors. However, this is not just about technical facilities, the quality of Internet access or teachers' digital competences. Equally important, if not more important, seems to be the involvement and methodological skills of teachers, as well as their flexibility, openness and willingness to seek new ways of organising the teaching and learning process. Preliminary assessments of the course of online learning in the school year 2019/2020 reveal that these teachers, who were also involved in genuinely supporting the development of their students before the pandemic, those who had already given students a choice, promoted their cooperation and tried to ensure that students understood the goal and saw the usefulness of the knowledge and skills acquired in the educational process. The teachers we investigated while they were implementing the UDL approach certainly belong to this group (Mach, 2020). 
An important change has also taken place in students' learning activity and their personal competences. Those who were taught, they became those who learn for themselves. They became (because it is certainly not a completed process) persons who are able to select and critically evaluate information and think about it briefly. Education during the pandemic has therefore proven to be an opportunity to increase the independence, capacity and creativity of students. Students 'moved' when teachers 'paused' (Ścibor, 2020, 59).

The results of the action research described in this chapter confirm the effectiveness of the UDL and the benefits of applying this philosophy (because this is how we ultimately understand UDL) in working with diverse learners, both for educational and social development. As in the sources mentioned above, it has been illustrated that the UDL contributes to reforming the learning process, optimising it and creating favourable conditions for inclusion. It should be noted, however, that the adopted research assumptions focused researchers' attention on only selected aspects of the learning process. Reflection on the results obtained and the phenomena observed in the course of collecting empirical material stir new questions and open up a further perspective for research on the implementation of the UDL approach in everyday school work.

The reflections presented here are merely a prelude to the necessary discussion on how, despite online education, to not only maintain, but also to develop, the idea of inclusive education. The question of what promotes the optimisation of online education is so well-established that, probably even after the pandemic, 'the world will no longer be as we know it' (Lubacz, 2020, 5). In addition, after a period of expected returning to a new normality, it is worth taking advantage of the positive experience of online education and partly linking it to traditional education within the walls of the school.

Interestingly, it is noted that the COVID-19 pandemic period 'astonishingly shows how topical the question of teaching forms is, as their advantages and disadvantages were formulated two thousand years ago' (Bartol, 2020, 9). This is a dispute between ancient philosophers initiated at that time, related to two different models of knowledge transfer. Plato claimed that the only valuable form of contact between pupils and teachers was direct contact and oral communication, whereas Socrates approved written texts that also made it possible to contact another person's mind without the need to meet him in person. The long history of education has shown that both of these models of knowledge transfer can perfectly coexist and complement each other. It will probably be the same, after the pandemic has ceased, with at-school and on-line education:

It seems that in education after pandemic, as always and everywhere, the ancient principle of the golden means will work. A non-reflective, theoretically possible at almost all stages of education, moving into the virtual world would dehumanize not only the teaching process itself, but also all of us. On the other hand, a stubborn and complete rejection of the skills and experiences acquired in an emergency would be proof of our carefree, misunderstanding of the challenges posed by the modern world, and, finally, of intellectual laziness, so as not to say limiting. The most productive, interesting and most alluring is what is varied, which gives us the opportunity to choose what uses proven long-standing patterns 
while using the latest ways of coping in the world being created in the time of advanced technologies. (Bartol, 2020, 12)

Referring to the thoughts of ancient philosophers, as well as referring to the results presented in this book of action research, one can afford more reflection. UDL-based online learning in the early stages of the COVID-19 pandemic periodically contributed to sustaining the teaching-learning process. A high level of motivation of teachers and students to develop and continue in online lessons as a full-fledged teaching-learning process was observed. It allowed for the maintenance of an effective cooperation between teachers, students and parents and between students. There has also been noticed an increase of student skills in planning, organising and managing the process of their own learning, as well as the development of their self-reliance, responsibility, creativity and problem-solving skills. As a result, they have become more active (self-learning improving). Teachers, on the other hand, took on the role of facilitator; they tried to create optimal conditions for the teaching-learning process in this diverse group of students. The general changes were thus conducive to implementing the basis for inclusive education.

On the other hand, it should be made clear that the protracted period of online learning associated with the unexpectedly long duration of the pandemic ${ }^{2}$ poses a real threat to the teaching-learning process and inclusive education. Teachers, pupils and parents feel tired of such a prolonged period of crisis and all of them want the return to education based on direct contact between teachers and pupils in a school building.

When considering the future, it is worth noting that the UDL philosophy can prove to be a very useful tool after coming back to education within the walls of the school. It is important to be aware that students will require a number of innovative actions in order to learn to be together again and to work together. Further, teachers will need to create synergies and build on the diversity of the learning community as well as on the educational process. In order to meet this extremely difficult task, everything should be done to ensure that the educational environment is organised in the most universal and optimal way (based on UDL principles), so that students and teachers re-learn to function in the school reality and so that students who, after the pandemic period, seem to have even more diverse needs, have access to and can participate in re-creating the school community, and this is a challenge for live inclusion.

\section{References}

Amilkiewicz-Marek, A. (2020). Rola rodziców w edukacji zdalnej uczniów ze specjalnymi potrzebami edukacyjnymi (The role of parents in online education of students with special educational needs). In E. Domagała-Zyśk (Ed.), Zdalne uczenie się i nauczanie a specjalne

\footnotetext{
${ }^{2}$ At the time of submission of this book for printing, the third semester of education took place in an online form.
} 
potrzeby edukacyjne. Z doświadczeń pandemii COVID-19 (Online learning and teaching and special educational needs. From COVID-19 pandemic experience) (pp. 129-164). Lublin: Wydawnictwo Episteme (Episteme Publishing House).

Bąbka, J., \& Korzeniowska, R. (2020). Jedność w różnorodności w perspektywie edukacji inkluzyjnej oraz uczenia się we współpracy (Unity in diversity in inclusive education and collaborative learning). Człowiek - Niepetnosprawność - Społeczeństwo (Human-DisabilitySociety), 2(48), 47-58.

Bartol, K. (2020). Nihil novi sub sole? Stare pytania. Jakie odpowiedzi? (Nihil novi sub sole? Old questions. What answers?). In Nauczanie po pandemii. Nowe pytania czy nowe odpowiedzi na stare pytania? (Teaching after a pandemic. New questions or new answers to old questions?) (pp. 9-14). Warsaw: Instytut Problemów Współczesnej Cywilizacji im. Marka Dietricha. LXXII, Wydawnictwo SGGW (Institute of Problems of Modern Civilization named after Mark Dietrich. LXXII, SGGW Publishing House).

Cellary, W. (2020). Edukacja w świetle pandemii (Education in the light of a pandemic). In Nauczanie po pandemii. Nowe pytania czy nowe odpowiedzi na stare pytania? (Teaching after a pandemic. New questions or new answers to old questions?) (pp. 15-24). Warsaw: Instytut Problemów Współczesnej Cywilizacji im. Marka Dietricha. LXXII, Wydawnictwo SGGW (Institute of Problems of Modern Civilization named after Mark Dietrich. LXXII, SGGW Publishing House).

Creswell, J. W. (2013). Projektowanie badań naukowych. Metody jakościowe, ilościowe i mieszane (Design of scientific research. Metody jakościowe, ilościowe i mieszane). Cracow: Wydawnictwo Uniwersytetu Jagiellońskiego (Jagiellonian University Publishing House).

Czerepaniak-Walczak, M. (2014). Badanie w działaniu w kształceniu i doskonaleniu nauczycieli. (Research in action in teacher education and training). Przegląd Badań Edukacyjnych (Educational Research Review), 19(2), 181-194.

European Agency for Development in Special Needs Education (EADSNE). (2011). Key principles for promoting quality in inclusive education - Practical recommendations. Odense: European Agency for Development in Special Needs Education.

Furmanek, W. (2014). Niektóre pedagogiczne konsekwencje nadmiarowości informacji (Some pedagogical consequences of information redundancy). In W. Wawer \& M. Pakuła (Eds.), Technologie informacyjno-komunikacyjne w edukacji XXI wieku (Information and communication technologies in 21st century education). Lublin: Wydawnictwo Lubelskiego Towarzystwa Naukowego (Scientific Society Publishing House).

Garwol, K. (2017). Wpływ digitalizacji życia na pogorszenie stanu zdrowia młodego człowieka. (The Influence of the Digitalization of Life on the Deterioration of the State of Health of a Youth). Edukacja - Technika - Informatyka (Education-Technology-Computer). Science, 2, 278-283.

Jemielniak, D. (2020). Zdalne nauczanie - blended, nie single malt (Online teaching-Blended, not single malt). In Nauczanie po pandemii. Nowe pytania czy nowe odpowiedzi na stare pytania? (Teaching after a pandemic. New questions or new answers to old questions?) (pp. 33-38). Warsaw: Instytut Problemów Współczesnej Cywilizacji im. Marka Dietricha. LXXII, Wydawnictwo SGGW (Institute of Problems of Modern Civilization named after Mark Dietrich. LXXII, SGGW Publishing House).

Kaczmarzyk, M. (2020). Neurobiologiczny kontekst edukacji zdalnej (Neurobiological context of online education). In J. Pyżalski (Ed.), Edukacja w czasach pandemii wirusa COVID-19. Z dystansem o tym, co robimy obecnie jako nauczyciele (Education in times of COVID-19 virus: Distanced from what we do now as teachers) (pp. 20-24). Warsaw: EduAkcja.

Koncewicz, M. (2020). Analiza rozwiązań prawnych dotyczących edukacji w czasie pandemii koronawirusa (Analysis of legal solutions for education during the coronavirus pandemic). In E. Domagała-Zyśk (Ed.), Zdalne uczenie się i nauczanie a specjalne potrzeby edukacyjne. $Z$ doświadczeń pandemii COVID-19 (Online learning and teaching and special educational needs. From the experience of the COVID-19 pandemic) (pp. 195-204). Lublin: Wydawnictwo Episteme (Episteme Publishing House). 
Kraśniewski, A. (2020). O jakości kształcenia w czasach COVID-19: stare odpowiedzi na nowe pytania (About the quality of education in the COVID-19 era: Old answers to new questions). In Nauczanie po pandemii. Nowe pytania czy nowe odpowiedzi na stare pytania? (Teaching after a pandemic. New questions or new answers to old questions?) (pp. 39-50). Warsaw: Instytut Problemów Współczesnej Cywilizacji im. Marka Dietricha. LXXII, Wydawnictwo SGGW (Institute of Problems of Modern Civilization named after Mark Dietrich. LXXII, SGGW Publishing House).

Kukułka, A. (2006). Dzieci i komputery - o plusach mówimy, a czy pamiętamy o zagrożeniach? (Children and computers - We talk about the pros, and do we remember the dangers?). In J. Baran \& S. Olszewski (Eds.), Świat peten znaczeń - kultura i niepetnosprawność (A world full of meanings - Culture and disability). Cracow: Oficyna Wydawnicza „Impuls” ('Impuls' Publishing House).

Lubacz, J. (2020). Zamiast wprowadzenia (Instead of introducing). In Nauczanie po pandemii. Nowe pytania czy nowe odpowiedzi na stare pytania? (Teaching after a pandemic. New questions or new answers to old questions?) (pp. 5-8). Warsaw: Instytut Problemów Współczesnej Cywilizacji im. Marka Dietricha. LXXII, Wydawnictwo SGGW (Institute of Problems of Modern Civilization named after Mark Dietrich. LXXII, SGGW Publishing House).

Mach, M. (2020). Co doświadczenie pandemii mówi nam o edukacji formalnej? (What does the pandemic experience tell us about formal education?). In Nauczanie po pandemii. Nowe pytania czy nowe odpowiedzi na stare pytania? (Teaching after a pandemic. New questions or new answers to old questions?) (pp. 73-82). Warsaw: Instytut Problemów Współczesnej Cywilizacji im. Marka Dietricha. LXXII, Wydawnictwo SGGW (Institute of Problems of Modern Civilization named after Mark Dietrich. LXXII, SGGW Publishing House).

Meyer, A., Rose, D. H., \& Gordon, D. (2014). Universal design for learning: Theory and practice. Wakefield: CAST Professional Publishing.

Pawlak, B. (2003). Jak wspótpracować z rodzicami uczniów klas początkowych? (How to work with parents of early education students?). Cracow: Wydawnictwo Naukowe Akademii Pedagogicznej (Pedagogical Academy Scientific Publishers).

Piecuch, A. (2016). Nowe media - nowe problemy (New media - New problems). Dydaktyka informatyki (Computer didactics), 1, 109-116.

Pilch, T., \& Bauman, T. (2010). Zasady badań pedagogicznych. Strategie ilościowe i jakościowe (Pedagogical research principles. Quantitative and qualitative strategies). Warsaw: Wydawnictwo Akademickie ,Żak” ('Żak’ Academic Publishers).

Plichta, J. (2020). Różne konteksty nierówności cyfrowych a wyzwania dla zdalnej edukacji propozycje rozwiazań (Different contexts of digital inequalities and challenges for online education - Solution proposals). In J. Pyżalski (Ed.), Edukacja w czasach pandemii wirusa COVID-19. Z dystansem o tym, co robimy obecnie jako nauczyciele (Education in times of COVID-19 virus: Distanced from what we do now as teachers) (pp. 70-80). Warsaw: EduAkcja.

Poleszak, W., \& Pyżalski J. (2020). Psychologiczna sytuacja dzieci i młodzieży w dobie pandemii (Psychological situation of children and young people in the era of pandemic). In J. Pyżalski (Ed.), Edukacja w czasach pandemii wirusa COVID-19. Z dystansem o tym, co robimy obecnie jako nauczyciele (Education in times of COVID-19 virus: Distanced from what we do now as teachers) (pp. 7-15). Warsaw: EduAkcja.

Pyżalski, J. (2020). Co jest obecnie ważne, a co mniej ważne w działaniach szkół i nauczycieli (What is now important and what is less important in the activities of schools and teachers). In J. Pyżalski (Ed.), Edukacja w czasach pandemii wirusa COVID-19. Z dystansem o tym, co robimy obecnie jako nauczyciele (Education in times of COVID-19 virus: Distanced from what we do now as teachers) (pp. 25-27). Warsaw: EduAkcja.

Pyżalski, J., \& Poleszak, W. (2020). Relacje przede wszystkim - nawet jeśli obecnie jedynie zapośredniczone (Relationships first of all - Even if currently only mediated). In J. Pyżalski (Ed.), Edukacja w czasach pandemii wirusa COVID-19. Z dystansem o tym, co robimy obecnie jako nauczyciele (Education in times of COVID-19 virus: Distanced from what we do now as teachers) (pp. 28-36). Warsaw: EduAkcja. 
Raport Sytuacja w edukacji w czasie pandemii (Pandemic Education Situation Report). https://bit. ly/raportSytuacjaWEdukacji. Accessed 6 Nov 2020.

Rose, D. H., Gravel, J. W., \& Gordon, D. T. (2014). Universal design for learning. In L. Florian (Ed.), Sage handbook of special education (pp. 475-489). Los Angeles/London/New Delhi/ Singapore/Washington, DC: Sage.

Rose, D. H., Meyer, A., \& Hitchcock, C. (2005). The universally designed classroom: Accessible curriculum and digital technologies. Cambridge: Cambridge University Press.

Sagor, R. (2008). Badanie przez działanie. Jak wspólnie badać, żeby lepiej uczyć (Research through action. How to do research jointly to teach better). Warsaw: Centrum Edukacji Obywatelskiej (Centre for Citizenship Education).

Skowron, B. (2020). Zmagania ze zdalną edukacją w akademii, szkole i przedszkolu (Struggles with online education in the academy, school and kindergarte). In Nauczanie po pandemii. Nowe pytania czy nowe odpowiedzi na stare pytania? (Teaching after a pandemic. New questions or new answers to old questions?) (pp. 125-146). Warsaw: Instytut Problemów Współczesnej Cywilizacji im. Marka Dietricha. LXXII, Wydawnictwo SGGW (Institute of Problems of Modern Civilization named after Mark Dietrich. LXXII, SGGW Publishing House).

Sterna, D. (2020). Ocenianie $w$ dobie koronawirusa (Judging in the era of coronavirus). In J. Pyżalski (Ed.), Edukacja w czasach pandemii wirusa COVID-19. Z dystansem o tym, co robimy obecnie jako nauczyciele (Education in times of COVID-19 virus: Distanced from what we do now as teachers) (pp. 64-69). Warsaw: EduAkcja.

Szmidt, K. J., \& Modrzejewska-Świgulska, M. (2015). Walidacja komunikacyjna w analizie wyników badań pedagogicznych (Communication validation in the analysis of pedagogical research results). Przeglad Badań Edukacyjnych (Educational Research Review), 2(19), 235-255.

Szymańska, M. (2018). Badania w działaniu (Research in action). In M. Ciechowska \& M. Szymańska (Eds.), Wybrane metody jakościowe w badaniach pedagogicznych (Selected qualitative methods in pedagogical research) (pp. 227-273). Cracow: Wydawnictwo WAM (The WAM Publishers).

Szymańska, M., Ciechowska, M., Pieróg, K., \& Gołąb, S. (Eds.). (2018). Badania w działaniu w praktyce pedagogicznej (Research in action in pedagogical practice). In Wybrane przyktady (Research in action in pedagogical practice: Selected examples). Cracow: Wydawnictwo Naukowe Akademii Ignatianum (Ignatianum Academy Scientific Publishers).

Ścibor, J. (2020). Wstrzymaj siebie, rusz ucznia: e-nauczanie a e-twórczość (Pause yourself, move the student: e-learning and e-creativity). In J. Pyżalski (Ed.), Edukacja w czasach pandemii wirusa COVID-19. Z dystansem o tym, co robimy obecnie jako nauczyciele (Education in times ofCOVID-19 virus: Distanced from what we do now as teachers) (pp. 59-63). Warsaw: EduAkcja.

Śliż, K. (2020). Doświadczenia nauczycieli w edukacji zdalnej podczas pierwszego etapu pandemii (Teacher experience in online education during the first stage of a pandemic). In E. Domagała-Zyśk (Ed.), Zdalne uczenie się i nauczanie a specjalne potrzeby edukacyjne. Z doświadczén pandemii COVID-19 (Online learning and teaching and special educational needs: From the experience of the COVID-19 pandemic) (pp. 95-128). Lublin: Wydawnictwo Episteme (Episteme Publishing House).

Tomczyk, Ł. (2020). Czego możemy się nauczyć od tych, którzy prowadzą zdalną edukację od dawna? (What can we learn from those who have been doing online education for a long time?). In J. Pyżalski (Ed.), Edukacja w czasach pandemii wirusa COVID-19. Z dystansem o tym, co robimy obecnie jako nauczyciele (Education in times of COVID-19 virus: Distanced from what we do now as teachers) (pp. 86-92). Warsaw: EduAkcja.

Walter, N. (2020). Mamy (za)duży wybór - jak nie zgubić się wśród narzędzi cyfrowych? (We have (too) big choice - How not to get lost among digital tools?). In J. Pyżalski (Ed.), Edukacja w czasach pandemii wirusa COVID-19. Z dystansem o tym, co robimy obecnie jako nauczyciele (Education in times of COVID-19 virus: Distanced from what we do now as teachers) (pp. 52-58). Warsaw: EduAkcja. 
Open Access This chapter is licensed under the terms of the Creative Commons Attribution 4.0 International License (http://creativecommons.org/licenses/by/4.0/), which permits use, sharing, adaptation, distribution and reproduction in any medium or format, as long as you give appropriate credit to the original author(s) and the source, provide a link to the Creative Commons license and indicate if changes were made.

The images or other third party material in this chapter are included in the chapter's Creative Commons license, unless indicated otherwise in a credit line to the material. If material is not included in the chapter's Creative Commons license and your intended use is not permitted by statutory regulation or exceeds the permitted use, you will need to obtain permission directly from the copyright holder.

(c) (i) 